Leszek Szewczyk ${ }^{1}$

Uniwersytet Śląski w Katowicach

\title{
Kierunki badań w homiletyce polskiej na podstawie zawartości Bibliografii homiletycznej
}

Ludwik Flaszen, współczesny pisarz, eseista i krytyk literacki, wskazał na nieprzemijającą wartość bibliografii. „Właściwie bibliografia ma swoje ogromne znaczenie, nie tylko rzeczowe, nie tylko dokumentacyjne. Także metafizyczne. Zmieniają się gusta, starzeją się prawdy, blaknie sława. O nieśmiertelność na tej ziemi coraz trudniej. Przemija postać świata. Zostaje bibliografia. Jedyna pewna gwarantka nieśmiertelności”2.

1 Leszek Szewczyk - prezbiter archidiecezji katowickiej, doktor habilitowany nauk teologicznych w zakresie homiletyki, dyplomowany logopeda. Adiunkt w Katedrze Teologii Pastoralnej, Liturgiki, Homiletyki i Katechetyki Wydziału Teologicznego Uniwersytetu Śląskiego w Katowicach, Kierownik Studiów Doktoranckich WTL UŚ. Ważniejsze publikacje: Recepcja liturgicznego wymiaru homilii. Studium homiletyczne w świetle przepowiadania kapłanów archidiecezji katowickiej w latach 1972-1999, Katowice 2003; Polska bibliografia homiletyczna 1945-2005, Kraków 2007 (współredakcja); Odnowa przepowiadania słowa Bożego w (archi) diecezji katowickiej po Soborze Watykańskim II. Studium homiletyczne, Katowice 2009; Polityka na ambonie?, Kraków 2015 (współredakcja). Zainteresowania naukowe: teologia przepowiadania słowa Bożego, retoryczny wymiar przepowiadania. E-mail: leszek.szewczyk@ interia.pl.

2 L. Flaszen, Oracja na jubileusz, „Odra” 5 (2006), s. 18. 
Baza bibliograficzna pozwala każdemu zainteresowanemu zlokalizować poszukiwane książki, dysertacje, artykuły, streszczenia i recenzje. Jest cennym źródłem informacji o publikacjach ukazujących się w ramach danej dyscypliny naukowej. Dotyczy to zwłaszcza stale aktualizowanych bibliografii elektronicznych. Także nauki teologiczne doczekały się wielu bibliografii, wśród których można wymienić: Elektroniczną Bibliografię Nauk Teologicznych FID ${ }^{3}$, Bazę artykułów biblistyki polskiej $^{4}$, Bibliografię historii Kościoła ${ }^{5}$, Bibliografię historii Kościoła na Śląsku ${ }^{6}$, Bibliografię liturgiczną Alcuinus ${ }^{7}$, Bibliografię gnostycką ${ }^{8}$, Polską Bibliografię Antyku Chrześcijańskiego ${ }^{9}$, Bibliografię prawa kanonicznego $^{10}$, Bibliografię chrystologiczną ${ }^{11}$, Polską bibliografię pneumatologiczną 1946-2004 ${ }^{12}$, Polską Bibliografię Tomistyczną 1879-2004 ${ }^{13}$ oraz Bibliografię teologii moralnej i etyki ${ }^{14}$. Do tego grona należy również udostępniona w kwietniu 2008 roku Bibliografia homiletyczna ${ }^{15}$. Jest to elektroniczna baza bibliograficzna, będąca następstwem publikacji Polska bibliografia homiletyczna 1945-2005, która ukazała się w 2007 roku pod redakcją Wiesława Przyczyny i Leszka Szewczyka ${ }^{16}$. Celem niniejszego opracowania jest prezentacja kierunków badań w homiletyce polskiej na podstawie zawartości elektronicznej Bibliografii homiletycznej ${ }^{17}$.

3 http://biblio.fides.org.p (dostęp do wszystkich zasobów internetowych: 07.11.2016).

4 https://www.biblistyka.umk.pl.

5 http://bazy.biblioteka.uksw.edu.pl/bhk.php.

6 http://www.wtl.us.edu.pl/pdf/bks.pdf.

7 http://www.alcuinus.org.

8 http://www.wtl.us.edu.pl/e107_plugins/content/content.php?content.71.

http://bazy.biblioteka.uksw.edu.pl/bac.php.

10 http://www.wtl.us.edu.pl/e107_plugins/content/content.php?content.153.

11 http://chrystologia.pl.

12 http://www.fides.org.pl/cgi-bin/makwww/makwww.exe?BM=08.

13 http://it.dominikanie.pl/index.php?option=com_bibliografia\&Itemid=212\&lang=pl.

14 http://bazy.biblioteka.uksw.edu.pl/btm.php.

15 http://www.homiletyka.wtl.us.edu.pl.

16 Polska bibliografia homiletyczna 1945-2005, oprac. W. Przyczyna, L. Szewczyk, Kraków 2007.

17 Elektroniczna Bibliografia homiletyczna uzupełniana jest każdorazowo o nadesłane do moderatora nowe pozycje bibliograficzne. Z całą pewnością nie zawiera kompletnej literatury homiletycznej, jest bowiem wiele opracowań, których autorzy (a w wypadku prac magisterskich i licencjackich - promotorzy) nie nadesłali danego opisu bibliograficznego. 


\section{Znaczenie bibliografii}

Tworzenie bibliografii ma wielowiekową historię, sięgającą czasów starożytności, i ogromny dorobek związany z rozwojem kultury i piśmiennictwa. Bibliografia może stanowić odrębną publikację, ale może również stanowić element książek, artykułów w czasopismach, a nawet informacji o nowościach wydawniczych. W języku polskim pojęcie „bibliografia” ma kilka znaczeń. Najpierw może oznaczać spełniający określone zadania informacyjne uporządkowany spis piśmiennictwa. Dalej określa ogół spisów bibliograficznych, stanu bibliografii. I wreszcie oznacza metodykę sporządzania spisów bibliograficznych ${ }^{18}$.

Bibliografia dorobku piśmienniczego pełni funkcję dokumentowania działalności naukowej w zakresie danej dyscypliny lub specjalności. Głównym zaś jej celem jest zaspokojenie istniejącej lub przewidywanej potrzeby społecznej formułowanej przez pracowników naukowych, poszukujących konkretnej wiedzy dorosłych i młodzieży, instytucji naukowych i kulturalnych. Bibliografia taka, stanowiąc jedno ze źródeł informacji, powinna być udostępniana. To udostępnienie dokonuje się w wersji drukowanej lub elektronicznej ${ }^{19}$. Decydująca o jakości wyników podejmowanej pracy i efektywności w korzystaniu z baz bibliograficznych jest ich systematyczna aktualizacja. Coraz szerszy dostęp do źródeł elektronicznych zwiększa możliwość rzetelnego dokumentowania dorobku wydawniczego, zaś fundamentalną zasadą tworzenia spisów bibliograficznych powinna być ich kompletnośćc ${ }^{20}$.

Wydana w 2007 roku Polska bibliografia homiletyczna 1945-2005 stanowiła inspirację do utworzonej bazy elektronicznej Bibliografia homiletyczna. Wersja drukowana zawierała 3002 pozycje, z lat 1945-2005. Baza elektroniczna zawiera wszystkie te pozycje bibliograficzne, a po kilkunastu uzupełnieniach wzbogaciła się o dodatkowych 800 pozycji, które ukazały się w latach 2006-2015. Bibliografia homiletyczna dostarcza również informacji na temat różnych rodzajów publikacji poruszających problematykę przepowiadania

18 H. Hleb-Koszariska, O bibliografii dla niewtajemniczonych, Wrocław 1974, s. 14.

19 E. Tomczyńska, Bibliografia dorobku naukowego uczelni źródłem informacji w erze cyfrowych technologii na przykładzie Biblioteki Uniwersytetu Szczecińskiego, „Folia Bibliologica” 51 (2009), s. 94.

20 E. Tomczyńska, Bibliografia dorobku naukowego uczelni..., dz. cyt., s. 93. 
słowa Bożego. Odnotowano w niej 15 publikacji stanowiących element procedury habilitacyjnej, czyli tzw. rozpraw habilitacyjnych, 112 rozpraw doktorskich i 770 prac magisterskich. Rodzajem opracowania najczęściej występującym w Bibliografii jest artykuł naukowy (2494 pozycji). Kolejne miejsca zajmują recenzje (180 pozycji), książki (172) oraz sprawozdania (59).

\section{Autorzy i słowa kluczowe}

W latach 1945-1999 powstało w sumie około 680 prac dyplomowych o tematyce homiletycznej. Odnotowano 7 prac habilitacyjnych, 69 doktorskich i około 600 magisterskich i licencjackich. To przyczyniło się do wykształcenia licznego grona homiletów uwrażliwionych na problem posługi słowa oraz zwiększenia pól badawczych i otwarcia nowych perspektyw wiedzy ${ }^{21}$.

Obecnie homileci polscy zrzeszeni są w Stowarzyszeniu Homiletów Polskich liczącym 45 członków. Artykuł 6 statutu Stowarzyszenia określa podstawowe cele, którymi są: „,prowadzenie badań naukowych w zakresie homiletyki, poszukiwanie nowych sposobów i form przepowiadania w kontekście współczesnych wyzwań, troska o kształcenie homiletów i jakość przepowiadania słowa Bożego w Polsce"22. Obecnie wśród członków Stowarzyszenia jest 4 profesorów tytularnych, 11 doktorów habilitowanych, 23 doktorów, 5 licencjatów kanonicznych oraz 2 magistrów. To oni stanowią grono najbardziej aktywnych naukowo homiletów.

W Bibliografii homiletycznej odnotowano publikacje 1406 autorów. Ponad połowę z nich stanowią autorzy prac magisterskich. Do najbardziej aktywnych pisarsko homiletów, których prace odnotowano w Bibliografii, należą: Kazimierz Panuś (233 pozycje), Gerard Siwek (198), Jan Twardy (175), Wiesław Przyczyna (156), Henryk Sławiński (132), Antoni Lewek (98), Stanisław Dyk (80) i Leszek Szewczyk (79) ${ }^{23}$.

${ }^{21}$ J. Twardy, Stan polskiej homiletyki w latach 1945-1999. Próba oceny i wnioski na przyszłość „Przegląd Pastoralno-Homiletyczny” 4 (2000), s. 17-37.

22 http://www.homileci.pl/statut (06.11.2016).

23 W dalszej kolejności: Waldemar Wojdecki (49), Herbert Simon (46), Mieczysław Brzozowski (42), Wojciech Pazera (42), Andrzej Draguła (36), Włodzimierz Broński (34), Tadeusz Lewandowski (33), Marian Rzeszewski (32), Adam Kalbarczyk (30) i Leszek Kuc (29). 
W indeksie słów kluczowych Bibliografii znajduje się 707 pozycji. Ponad połowa z nich (357) odnosi się do konkretnych osób, u których przeprowadzono studium ich kaznodziejskiego dorobku. Pozostałe 350 haseł odnosi się do całego spektrum zagadnień podejmowanych w opracowaniach homiletycznych. Poniższa tabela ilustruje największą częstotliwość występowania poszczególnych haseł przedmiotowych:

\begin{tabular}{|l|c|}
\hline \multicolumn{1}{|c|}{ SŁOWA KLUCZOWE } & N \\
\hline historia kaznodziejstwa & 591 \\
\hline studium dorobku kaznodziejskiego & 482 \\
\hline Biblia w przepowiadaniu, Ewangelia (Dobra Nowina), słowo Boże & 446 \\
\hline $\begin{array}{l}\text { liturgia, liturgika, liturgia a przepowiadanie, rok liturgiczny, sakramenty w prze- } \\
\text { powiadaniu }\end{array}$ & 414 \\
\hline $\begin{array}{l}\text { forma przepowiadania, dykcja (wymowa, fonetyka), dialog w przepowiadaniu, ko- } \\
\text { munikacja (werbalna, niewerbalna) obrazowość w przepowiadaniu, język homilii } \\
\text { (kazania), język polski, język religijny }\end{array}$ & 388 \\
\hline homilia & 309 \\
\hline przepowiadanie słowa Bożego (istota, cel, zadania) & 234 \\
\hline ewangelizacja, nowa ewangelizacja & 189 \\
\hline głosiciel słowa Bożego, głoszenie słowa Bożego & 183 \\
\hline rekolekcje (dla dzieci, dla młodzieży, parafialne, szkolne, zamknięte) & 160 \\
\hline kerygmat & 140 \\
\hline homiletyka & 128 \\
\hline kazanie (budowa, przymioty) & 116 \\
\hline dydaktyka homiletyki, formacja homiletyczna & 90 \\
\hline słuchacz, słuchanie słowa Bożego & 90 \\
\hline misje ludowe & 82 \\
\hline problematyka moralna i społeczna & 45 \\
\hline retoryka w przepowiadaniu & 28 \\
\hline literatura a przepowiadanie, literackość kazań & 82 \\
\hline mistagogia & 38 \\
\hline
\end{tabular}

Powyższa tabela obejmuje występowanie słów kluczowych całego piśmiennictwa z zakresu homiletyki w latach 1945-2015 zamieszczone- 
go w Bibliografii homiletycznej. Baza ta pomaga wskazać kierunki badań naukowych w poszczególnych etapach tego liczącego 70 lat okresu. Poszczególne krótsze okresy oraz kierunki rozwoju myśli homiletycznej były już omawiane we wcześniejszych opracowaniach. Pierwszy obszerniejszy spis polskiej bibliografii homiletycznej adnotowanej zamieścił Antoni Lewek. Znaczna część książki Wspótczesna odnowa kaznodziejstwa, z. 1: Z najnowszych dziejów ruchu homiletycznego zawiera opis działalności instytucjonalnej na rzecz kaznodziejstwa, rozwoju myśli homiletycznej inspirującej jego odnowę oraz wspomnianą polską bibliografię homiletyczną adnotowaną ${ }^{24}$. Kolejną publikacją, która wskazywała zwłaszcza na ilościowe dane dotyczące bibliografii homiletycznej, był artykuł Jana Twardego Stan polskiej homiletyki w latach 1945-1999. Próba oceny i wnioski na przyszłośćc ${ }^{25}$. Wspomniane wyżej opracowania nie tylko ukazywały bogactwo piśmiennictwa podejmującego zagadnienia homiletyczne, ale również omawiały kierunki rozwoju homiletyki polskiej. Problematykę kierunków rozwoju homiletyki polskiej podejmował także artykuł Leszka Kuca ukazujący stan homiletyki polskiej po soborze watykańskim II do roku $1969^{26}$ oraz opracowanie Herberta Simona omawiające to samo zagadnienie, ale w znacznie dłuższym okresie (1965-2005) ${ }^{27}$. Przemiany we współczesnej homiletyce fundamentalnej analizował w kolejnym artykule Jan Twardy ${ }^{28}$.

\section{Postulaty dotyczące homiletyki polskiej}

We wspomnianych powyżej opracowaniach ukazano kierunki badań w homiletyce polskiej oraz przedstawiono postulaty dotyczące dalsze-

24 A. Lewek, Ruch homiletyczny w Polsce w latach 1945-1976. Jest to część druga książki Wspótczesna odnowa kaznodziejstwa, z. 1. Z najnowszych dziejów ruchu homiletycznego, Warszawa 1980, s. 80-252.

25 J. Twardy, Stan polskiej homiletyki..., dz.cyt., s. 17-37.

26 L. Kuc, Homiletyka polska po Soborze Watykańskim II, w: Posoborowe publikacje teologiczne w Polsce, red. J. Myśków, B. Przybyszewski, Warszawa 1969, s. 226-233.

27 H. Simon, Homiletyka polska 1965-2005, w: Polska bibliografia homiletyczna 1945-2005, oprac. W. Przyczyna, L. Szewczyk, Kraków 2007, s. 15-41.

${ }_{28}$ J. Twardy, Źródła przemian we współczesnej homiletyce fundamentalnej, „Śląskie Studia Historyczno-Teologiczne" 39 (2006) nr 1, s. 112-125. 
go rozwoju tej dyscypliny teologicznej. Stwierdzono systematyczny rozwój polskiej myśli homiletycznej w zakresie homiletyki fundamentalnej. Opracowania naukowe dotyczące tematów podstawowych w polskiej homiletyce są dojrzałe i obficie reprezentowane. Pojawia się jednak propozycja całościowego opracowania tej problematyki w formie podręcznikowej ${ }^{29}$. Wśród postulatów wysuwanych przez Herberta Simona najważniejsze są: konieczność podejmowania badań ukazujących recepcje nauki Kościoła na temat przepowiadania słowa Bożego w polskiej praktyce kaznodziejskiej; koncentracja w badaniach na specyfice regionalnej (zakonnej) przepowiadania; w kontekście nowej ewangelizacji ukazywanie priorytetowej roli homilii i jej mistagogicznego i chrystocentrycznego wymiaru; podejmowanie szeroko rozumianej antropologii homiletycznej, ze szczególnym uwzględnieniem nowej retoryki ${ }^{30}$. Kolejne postulaty dotyczące badań podejmowanych przez homiletów formułuje Jan Twardy. Zauważył on konieczność omówienia i podsumowania posoborowych statutów polskich synodów diecezjalnych oraz opracowania programu permanentnej formacji homiletycznej duchowieństwa. Wskazał również na pilną potrzebę opracowań dotyczących historii homiletyki polskiej w ostatnim, najnowszym okresie oraz zbadania jej kierunków rozwoju. Dalsze prace homiletów polskich powinny również, jego zdaniem, zmierzać do przygotowania słowników i innych pomocy leksykograficznych, np. małego i dużego słownika homiletycznego, zawierającego pojęcia i hasła z tej dziedziny, oraz opracowanie małego i dużego słownika polskich homiletów ${ }^{31}$.

\section{Najnowsze kierunki badań homiletycznych}

Niektóre z przedstawionych powyżej postulatów nie straciły swojej aktualności, inne wydają się w dużym stopniu zrealizowane. Kierunki najnowszych badań znajdują odzwierciedlenie w publikacjach odnoto-

\footnotetext{
29 J. Twardy, Źródła przemian we współczesnej homiletyce fundamentalnej, dz. cyt., s. 122.

30 H. Simon, Homiletyka polska 1965-2005..., dz. cyt., s. 40, 41.

31 J. Twardy, Stan polskiej homiletyki..., dz. cyt., s. 34-37.
} 
wanych w Bibliografii homiletycznej. Baza ta w latach 2006-2015 wzbogaciła się o 800 dodanych opracowań dotyczących zagadnień homiletycznych. Analizowane publikacje można usystematyzować w kilku głównych grupach tematycznych. Obszerną część publikacji można przypisać do działu historia kaznodziejstwa i studium dorobku kaznodziejskiego. Inną znaczną część publikacji homiletycznych zamieszczonych w Bibliografii homiletycznej można określić mianem teologii przepowiadania. Homileci polscy analizują również problematykę dotyczącą podmiotu przepowiadania, teologii homilii, jej mistagogicznego wymiaru, biblijnego i liturgicznego źródła przepowiadania homilijnego, formalnej strony wypowiedzi kaznodziejskiej, dydaktyki homiletyki i formacji homiletycznej. W najnowszych publikacjach poruszano również zagadnienia przepowiadania słowa Bożego w kontekście nowej ewangelizacji oraz podczas misji i rekolekcji parafialnych.

Znacząca część publikacji podejmuje zagadnienia związane z historią kaznodziejstwa. W dużej mierze jest to zasługa Kazimierza Panusia. Do wydanych we wcześniejszym okresie dzieł tego autora dołączyło trzytomowe opracowanie Kazania w kulturze polskiej. Edycje kolekcji tematycznych ${ }^{32}$. W tym samym okresie Kazimierz Panuś opublikował w krakowskich „Materiałach Homiletycznych” cykl Słynne kazania polskie. Liczący kilkadziesiąt pozycji zbiór to cenny materiał analizujący dawne kaznodziejstwo polskie, a jednocześnie źródło pomocne w dydaktyce historii kaznodziejstwa.

Zagadnieniem często podejmowanym przez współczesnych homiletów polskich jest również teologia przepowiadania. Wśród autorów podejmujących to zagadnienie należy wymienić między innymi ${ }^{33}$ : Andrzeja Dragułę ${ }^{34}$,

32 K. Panuś, Kazania w kulturze polskiej. Edycje kolekcji tematycznych, t. 1: Kazania maryjne, Kraków 2014; K. Panuś, Kazania w kulturze polskiej. Edycje kolekcji tematycznych, t. 2: Kazania funeralne, Kraków 2014, K. Panuś, Kazania w kulturze polskiej. Edycje kolekcji tematycznych, t. 3: Kazania pasyjne, Kraków 2014.

33 W przypisach znajdują się wybrane publikacje. Zamieszczenie wszystkich opracowań z danego zakresu przekraczałoby ramy objętościowe artykułu naukowego.

34 A. Draguła, Przepowiadanie jako wewnętrzny dialog Słowa, w: W dialogu ze Słowem. Biblia w katechezie i nauczaniu religii, red. K. Kantowski, Szczecin 2011, s. 67-82. 
Stanisława Dyka ${ }^{35}$, Wiesława Przyczynę $e^{36}$, Gerarda Siwka ${ }^{37}$, Henryka Sławińskiego ${ }^{38}$, Leszka Szewczyka ${ }^{39}$, Wojciecha Turowskiego ${ }^{40}$, Jana Twardego ${ }^{41}$ i Edwarda Wiszowatego ${ }^{42}$. Jednym z najczęściej podejmowanych zagadnień $\mathrm{w}$ ramach teologii przepowiadania jest problem podmiotu, szczególnie zaś temat głosiciela słowa Bożego. Zagadnienie to jest często omawiane w polskiej literaturze homiletycznej ostatniego dziesięciole$\mathrm{cia}^{43}$. Dla teologii przepowiadania jednym z najważniejszych zagadnień

35 S. Dyk, Relacja między przepowiadaniem słowa Bożego a Kościołem, „Kieleckie Studia Teologiczne" 7 (2008), s. 27-42; S. Dyk, Podmiot przepowiadania homilijnego w świetle współczesnych dokumentów Kościoła, „Kieleckie Studia Teologiczne” 8 (2009), s. 283-297; S. Dyk, Współczesne kierunki teologicznej refleksji nad przepowiadaniem, w: Kościół - komunia i dialog. Księga pamiątkowa ofiarowana Księdzu Biskupowi Kazimierzowi Ryczanowi w 75. rocznicę urodzin, red. P. Kantyka, J. Czerkawski, T. Siemieniec, Kielce 2014, s. 463-476.

36 W. Przyczyna, O metodologii homiletyki, „Studia Nauk Teologicznych PAN” 2 (2007), s. 289-300, W. Przyczyna, G. Siwek, Homiletyka - teologia przepowiadania czynauka o podstawach?, w: W trosce o dobrąedukację, red. A. Janus-Sitarz, Kraków 2009, s. 448-460; W. Przyczyna, G. Siwek, Metodologia teologii homiletycznej, w: Metodologia teologii praktycznej, red. W. Przyczyna, Kraków 2012, s. 70-84.

37 G. Siwek, Przepowiadanie słowa Bożego, w: Leksykon teologii pastoralnej, red. R. Kamiński, W. Przygoda, M. Fijałkowski, Lublin 2006, s. 696-702; G. Siwek, Blaski i cienie współczesnego przepowiadania, Kraków 2007.

38 H. Sławiński, Homiletyka $w$ dobie nowej ewangelizacji, „Acta. Facultatis Theologicae Universitatis Comenianae Bratislaviensis" 8 (2011) nr 2, s. 12-26; H. Sławiński, Ludzki wkład w skuteczność przepowiadania słowa Bożego, „Polonia Sacra” 15 (2011) nr 28, s. 227-241; H. Sławiński, Podmiot przepowiadania słowa w liturgii, w: Liturgia a przepowiadanie, red. W. Przyczyna, Kraków 2010, s. 93-112.

39 L. Szewczyk, Odnowa przepowiadania słowa Bożego w (archi)diecezji katowickiej po Soborze Watykańskim II. Studium homiletyczne, dz.cyt.

40 W. Turowski, Verbum Domini wyzwaniem dla wspótczesnej homiletyki, w: Aksjologiczne aspekty Pisma Świętego. Wokół Verbum Domini, red. Z. Struzik, A. Najda, Warszawa 2012, s. 65-80.

${ }_{41} \mathrm{~J}$. Twardy, Aktualizacja słowa Bożego w kaznodziejstwie, Przemyśl 2009; J. Twardy, Chrystocentryzm w kaznodziejskiej posłudze słowa, „Śląskie Studia Historyczno-Teologiczne” 40 (2007) z. 1, s. 50-64, J. Twardy, Istota i cele kaznodziejskiej posługi słowa Bożego, w: Omnia tempus habent. Miscellanea theologica Vincentio Myszor quadragesimum annum laboris scientifici celebranti ab amicis, sodalibus discipulisque oblata, red. A. Reginek, G. Strzelczyk, A. Żądło, Katowice 2009, s. 292-306.

42 E. Wiszowaty, Przepowiadanie w ponowoczesności, „Studia Pastoralne” 9 (2013), s. 178-190.

43 S. Dyk, Kaznodzieja apostołem Jezusa. Przyczynek do duchowości głosiciela słowa Bożego na podstawie Ewangelii wg św. Marka, w: Kapłan w posłudze słowa Bożego, red. L. Szewczyk, W. Sztyk, Katowice 2010, s. 36-45; A. Kalbarczyk, W komunii ze słowem. Duchowośćkaznodziei, w: Iustitiam in caritate. Opuscula Georgio Troska septuagenario dedicata, red. D. Bryl, F. Lenort, Poznań 2012, s. 201211; D. Kwiatkowski, Prezbiter szafarzem sakramentów i głosicielem Słowa Bożego w wybranych poso- 


\section{jest teologia homilii. W publikacjach homiletycznych wskazuje się na jej pochodzenie ${ }^{44}$, definicję ${ }^{45}$, znaczenie i funkcje ${ }^{46}$, poszczególne jej wymia- $\mathrm{ry}^{47}$, jej liturgiczny kontekst ${ }^{48}$ oraz konieczność ciągłego jej poprawiania ${ }^{49}$.}

borowych dokumentach Kościoła, „Liturgia Sacra” 44 (2014) nr 2, s. 349-361; G. Siwek, Osobowość kaznodziei dzisiaj. Rozważania nieobojętne, Kraków 2014; H. Sławiński, Kapłan kaznodzieja głoszaccy z moca, w: Kapłan w posłudze słowa Bożego, dz.cyt., s. 24-35; H. Sławiński, Źródła autorytetu kaznodziei, „Ateneum Kapłańskie” (2010) nr 606, s. 313-324; H. Sławiński, Celebrans jako zwyczajny głosiciel homilii we Mszy świętej, „Ateneum Kapłańskie” (2003) nr 564, s. 246-258; H. Sławiński, Głosiciel homilii według współczesnych dokumentów Kościoła, w: W Panu złożyłem nadzieje, red. R. Andrzejewski i in., Włocławek 2002, s. 381-397.

${ }_{44}$ H. Sławiński, Judaistyczne korzenie współczesnej homilii, w: Ekumenizm, teologia, kultura, red. K. Konecki, Z. Pawlak, K. Rulka, Włocławek 2006, s. 488-501.

45 W. Broński, Homilia, w: Leksykon teologii pastoralnej, dz. cyt., s. 288-291; W. Przyczyna, Homilia pięćdziesiąt lat po Soborze Watykańskim II. Pytania, problemy, wyzwania, Kraków 2013; H. Sławiński, Ewaluacja homilii, „Studia Włocławskie” 9 (2006), s. 194-203; H. Sławiński, Odmienne koncepcje homilii, ich egzemplifikacja i komparatywna analiza, „Studia Pastoralne” 5 (2009), s. 198-212; J. Twardy, Czym homilia nie jest - błędy w jej głoszeniu, „Roczniki Teologiczne” 62 (2015) z. 12, s. 47-62, J. Twardy, Przemiany w polskiej teorii homilii pod wpływem nauki Soboru Watykańskiego II, w: Wierność i aggiornamento. Wokół recepcji Soboru Watykańskiego II, red. G. Kucza, Katowice 2006, s. 205-220.

46 A. Kalbarczyk, Egzystencjalny, personalny i eklezjalny wymiar homilii pogrzebowej, „Przegląd Homiletyczny" 15 (2011), s. 135-147; W. Przyczyna, Funkcje homilii. Aspekt teologiczny, w: Funkcje wypowiedzi religijnych, red. R. Przybylska, W. Przyczyna, Tarnów 2013, s. 145154; L. Szewczyk, Funkcje homilii i jej rola w liturgii, w: Liturgia w podstawowych formach wyrazu, red. A. Żądło, Katowice 2011, s. 119-135; L. Szewczyk, Znaczenie, funkcje i miejsce homilii w liturgii, w: Praedicamus Christum crucifixum. Słowo Boże w liturgii Kościoła. Księga Jubileuszowa dedykowana Księdzu Arcybiskupowi Damianowi Zimoniowi Metropolicie Katowickiemu w 25 rocznice święceń biskupich, red. A. Żądło, Katowice 2010, s. 171-180; W. Turowski, Funkcja homilii i katechezy mistagogicznej $w$ doprowadzaniu do źródeł wiary, w: Duszpasterstwo wobec kryzysu wiary, red. W. Przygoda, K. Święs, Lublin 2013, s. 243-263.

47 A. Draguła, Wtajemniczający charakter homilii, w: Funkcja inicjacyjna katechezy w Kościele współczesnym, red. K. Kantowski, Szczecin 2007, s. 289-306; S. Dyk, Homilijny przekaz prawd wiary, „Wrocławski Przegląd Teologiczny” 16 (2008) z. 1, s. 79-91; S. Dyk, Historiozbawczy wymiar przepowiadania homilijnego, „Przegląd Homiletyczny” 13 (2009), s. 7-17.

48 A. Bałabuch, Homiliajako integralna część liturgii słowa, w: Słowo Boże w liturgii. Obecność celebracja-aktualizacja, red. S. Araszczuk, Wrocław 2010, s. 113-123; S. Dyk, Homilia w niedzielnej Eucharystii, „Roczniki Teologiczne” 53 (2006) z. 8, s. 241-251; S. Dyk, Liturgia miejscem interpretacji słowa Bożego, „Zeszyty Naukowe KUL” (2010) nr 1, s. 33-46; W. Przyczyna, Miejsce homilii w celebracji liturgicznej, w: Liturgia i przepowiadanie, red. W. Przyczyna, Kraków 2010, s. 43-56; H. Sławiński, Liturgia słowa i liturgia eucharystyczna jakojeden akt liturgiczny, „Przegląd Homiletyczny" 11 (2007), s. 19-32.

49 W. Przyczyna, Czy księża liczą się z Magisterium Kościoła? (Na przykładzie homilii mszalnej), w: Kapłan w posłudze słowa Bożego, dz.cyt., s. 88-98; H. Sławiński, Potrzeba urozmaicenia 
Przepowiadanie homilijne, zwane też liturgicznym lub mistagogicznym, polega na wprowadzaniu, wtajemniczaniu wierzących w chrześcijańskie tajemnice ukryte pod osłoną znaków liturgicznych. Ma na celu ukazanie obecności i działania Chrystusa w liturgii i doprowadzenie do zjednoczenia z Nim. Przepowiadanie to dokonuje się w ramach sprawowania liturgii i przybiera postać homilii stanowiącej integralną część celebracji liturgicznej. Takie przepowiadanie jest mistagogiczne, naświetla ukryte rzeczywistości przez szersze powiązanie z liturgicznymi tekstami, wyjaśnia zbawczy sens znaków liturgicznych, doprowadza do centrum tajemnicy kultu i wprowadza w tajemnice zbawczego działania sakramentó $\mathrm{w}^{50}$. Opracowania na temat mistagogicznego wymiaru homilii opublikowali między innymi Andrzej Draguła ${ }^{51}$ i Stanisław Dyk ${ }^{52}$.

Homilia łączy w sobie trzy istotne dla niej elementy. Pierwszym z nich jest sprawowane misterium, drugim jest tekst biblijny ze swoim orędziem i aktualizacją, a trzecim aktualna sytuacja życiowa konkretnych słuchaczy. Przepowiadane orędzie zbawienia zawsze powinno łączyć się z liturgią, a jedno i drugie z życiem słuchaczy ${ }^{53}$. Według nauczania Kościoła posługa słowa powinna się opierać na Piśmie Świętym, Tradycji, liturgii, Nauczycielskim Urzędzie Kościoła i życiu Kościoła (KPK 760). Konstytucja o liturgii świętej II Soboru Watykańskiego stwierdza, że homilie powinny czerpać treść przede wszystkim ze źródeł Pisma Świętego i liturgii (KL 35), a konstytucja o objawieniu Bożym dodaje: „Tak całe przepowiadanie kościelne [...] musi się karmić Pismem Świętym i nim się kierować" (KO 21). Do problematyki związanej z biblijnym źródłem przepowiadania

modelu homilii, „Studia Włocławskie” 11 (2009), s. 90-97; J. Twardy, Konieczność poprawienia jakości homilii, w: Moc słowa Pańskiego. Adhortacja apostolska Verbum Domini w refleksji biblijnohomiletycznej, red. B. Migut, A. Piwowar, Lublin 2012, s. 249-266.

50 L. Szewczyk, Odnowa przepowiadania słowa Bożego..., dz. cyt., s. 202.

51 A. Draguła, Mistagogiczny wymiar homilii, w: Funkcja inicjacyjna katechezy w Kościele wspótczesnym, red. K. Kantowski, Szczecin 2007, s. 289-306.

52 S. Dyk, Mistagogiczna natura i funkcja homilii, „Przegląd Homiletyczny” 11 (2007), s. 103 112; S. Dyk, Mistagogiczna funkcja homilii pokutnej, „Przegląd Homiletyczny” 12 (2008), s. 111117; S. Dyk, Rola homilijnej mistagogii w dziele nowej ewangelizacji, w: Quod otaque Redemptoris nos tri conspicuum fuit, in sacramenta transivit. Sakramenty w misterium Kościoła. Księga dedykowana Księdzu Profesorowi Czesławowi Krakowiakowi z okazji siedemdziesiątych urodzin, red. B. Migut, Z. Głowacki, W. Pałęcki, Lublin 2014, s. 299-310.

53 W. Broński, Homilia..., dz. cyt., s. 288. 
homilijnego oraz interpretacji poszczególnych perykop biblijnych odwoływano się wielokrotnie ${ }^{54}$.

Homilia jest z natury wyjaśnieniem, wykładem i aktualizacją tekstu biblijnego i liturgicznego. Wykład tajemnic wiary i zasad chrześcijańskiego życia, jakim jest homilia, powinien być oparty na tekstach liturgicznych danego dnia. Homilista powinien nawiązywać do celebrowanej tajemnicy zbawienia i umożliwiać czerpanie mocy z Misterium Paschalnego i zespolić w homilii tekst biblijny z tekstem lub obrzędem liturgicznym. Wówczas te dwa obszary treściowe nawzajem się wyjaśniają, a liturgia otrzymuje tym samym, dzięki słowu Bożemu, swoje zbawcze wyjaśnienie ${ }^{55}$. Polscy homileci w ostatnim dziesięcioleciu wypowiadali się na temat wzajemnych relacji liturgii i przepowiadania homilijnego $0^{56}$, znaczenia lekcjonarza mszalnego ${ }^{57}$, głoszenia homilii podczas sakramentów i sakramentalió $w^{58}$ oraz w ciągu roku liturgicznego ${ }^{59}$. Znacznym zainteresowaniem polskich

54 S. Dyk, Wspótczesne przepowiadanie homilijne misteriówpublicznego życia Jezusa, Lublin 2008; S. Dyk, Zasady interpretacji tekstu biblijnego w praktyce kaznodziejskiej, „Perspectiva - Legnickie Studia Teologiczno-Historyczne" 14 (2009) z. 1, s. 99-121; S. Dyk, Zmartwychwstanie Jezusa Chrystusa jako fundament i treść przepowiadania homilijnego, „Scriptura Lumen” 2 (2010), s. 415-433; R. Kowalski, Przepowiadać atrakcyjnie. Pismo Święte źródłem przepowiadania, „Wrocławski Przegląd Teologiczny" 1 (2006), s. 173-180; T. Szałanda, Kuszenie Jezusa na pustyni (Mk 1, 12-13; Mt 4, 1-11; Łk 4, 1-13) w posoborowym przepowiadaniu polskim. Studium egzegetyczno-homiletyczne, Olsztyn 2007; S. Dyk, Homilie do tekstów Starego Testamentu. Zapomniana praktyka wspótczesnego kaznodziejstwa?, „Ateneum Kapłańskie” (2012) nr 622, s. 516-524; S. Dyk, Zwiastowanie Pańskie ( $€$ k1, 26-38) w przepowiadaniu homilijnym. Biblia w przepowiadaniu, t. 1, Siedlce 2013; F. Szymański, Biblia w przepowiadaniu. Kaznodziejski przekaz perykopy Łk 2, 22-40, „Homo Dei” (2007) nr 284, s. 170-179.

55 H. Simon, Kaznodziejstwo polskie: zdobycze i niedociagnięcia, „Ateneum Kapłańskie” (1993) nr 121, s. 253.

56 Zob. przypis 46.

57 S. Dyk, Układ Lekcjonarza mszalnego pomoca w interpretacji orędzia biblijnego, „Zeszyty Naukowe KUL" 52 (2009) nr 1, s. 61-71; S. Dyk, Co głosić, aby wierzyli. Studium homiletyczne Lekcjonarza mszalnego, Lublin 2013; J. Twardy, Tekst biblijny w liturgii, w: Liturgia w podstawowych formach wyrazu, red. A. Żądło, Katowice 2011, s. 91-118; J. Twardy, Lekcjonarz mszalny podstawą kaznodziejskiej interpretacji problemów moralno-politycznych, „Śląskie Studia Historyczno-Teologiczne" 48 (2015) z. 2, s. 388-404.

58 A. Kalbarczyk, Celebracja homilii w kontekście celebracji Eucharystii i niedzieli, „Colloquia Theologica Ottoniana” 1 (2012), s. 63-80, A. Kalbarczyk, Głoszenie słowa Bożego w ramach sakramentu pokuty i pojednania, w: „Nawracajcie się i wierzcie w Ewangelię”. Program duszpasterski Kościoła w Polsce na rok 2014/2015, red. S. Stułkowski, Poznań 2014, s. 253-268.

59 J. Twardy, Kaznodziejskie nauczanie o Duchu Świętym w roku liturgicznym, „Przegląd Homiletyczny” 10 (2006), s. 71-83; J. Twardy, Kaznodziejskie nauczanie o pokucie w roku liturgicznym, „Przegląd Homiletyczny” 12 (2008), s. 119-133. 
homiletów w okresie ostatniego dziesięciolecia cieszyły się zagadnienie formalne wypowiedzi kaznodziejskiej. Rozważaniem ludzkiej szaty słowa Bożego zajmuje się homiletyka formalna, która podejmuje takie zagadnienia, jak: metoda przygotowywania jednostki przepowiadania (homilia, kazanie), jej forma językowa, sposób wygłoszenia, osobowość podmiotu przepowiadania, znajomość słuchaczy itp. Ten dział homiletyki ma również teologiczny charakter. Dbałość o jakość ludzkiego słowa jest traktowana jako posługa słowu, a sama homiletyka formalna staje się refleksją o sposobach posługiwania ludzkim słowem słowu Bożemu ${ }^{60}$. Omawiano między innymi relacje między formą i treścią przepowiadania kaznodziejskiego ${ }^{61}$, znaczenie dialogu w kaznodziejstwie ${ }^{62}$, języka przepowiadania kaznodziejskiego ${ }^{63}$, literackości współczesnego przepowiadania ${ }^{64}$, fonetycznych kompetencji kaznodziei ${ }^{65}$ i wielu innych szczegółowych

${ }_{60}$ G. Siwek, Miejsce retoryki w homiletyce, w: Retoryka dziś. Teoriai praktyka, red. W. Przyczyna, Kraków 2001, s. 283-300.

${ }_{61}$ L. Szewczyk, Złoty środek kaznodziejstwa. O ciagłym napięciu między forma i treścia przepowiadania słowa Bożego, „Polonia Sacra” 14 (2010) nr 26, s. 53-66, L. Szewczyk, Adhortacja apostolska „Evangelii Gaudium” o formalnej stronie wypowiedzi kaznodziejskiej, w: red. M. Panek, J. Wilk, Gratias agamus Domino Deo nostro. Księga Honorowa dedykowana Księdzu Jerzemu Palińskiemu Rektorowi Wyższego Ślaskiego Seminarium Duchownego w Katowicach w latach 2006-2013, Katowice 2014, s. 262-271.

62 P. Gabara, Recepcja zjawiska komunikacyjnego w teologii liturgii i homiletyce, „Eódzkie Studia Teologiczne" 23 (2014) nr 4, s. 77-92; Z. Grzegorski, Od kogo - do kogo? Dialog w komunikacyjnym modelu przepowiadania, „Biblioteka Kaznodziejska” 151 (2007) z. 1, s. 18-23; G. Siwek, Dialog w głoszeniu słowa Bożego, „Biblioteka Kaznodziejska” 151 (2007) z. 2, s. 9-17; W. Turowski, Komunikacja słowa Bożego a komunikat zwrotny, „Roczniki Teologii Katolickiej” (2011), s. 144-160.

${ }_{63}$ A. Draguła, Językmiędzy wiarą a niewiara, „Więź” (2010) z. 2, s. 5-13; W. Ostafiński, Formy narracyjne we wspótczesnych tekstach homiletycznych, „Przegląd Homiletyczny” 12 (2008), s. 191205; W. Ostafiński, Funkcja ekspresywna we wspótczesnych tekstach homiletycznych, „Analecta Cracoviensia” 40 (2008), s. 263-284; W. Przyczyna, O języku kazań i nie tylko, „Materiały Homiletyczne” (2006) nr 231, s. 34-39; L. Szewczyk, „Siedziećjakna tureckim kazaniu”, czylio trudnym języku kazań, „Logopedia Silesianea” 3 (2014), s. 143-151; J. Twardy, Błędy w kaznodziejskiej komunikacji wokalno-werbalnej, w: Super omnia veritas. Ksiegga dedykowana ks. prof. Tadeuszowi Śliwie w 90. rocznicę urodzin i 50-lecie pracy naukowej, red. J. Wołczański, Lwów-Kraków 2015, s. 639-651.

64 J. Sikora, Literackość wspótczesnych kazań polskich, Warszawa 2008; J. Sikora, Współczesne kazanie wobec literackości, „Przegląd Homiletyczny” 14 (2010), s. 175-186.

65 L. Szewczyk, Co logopeda słyszy we współczesnych polskich kazaniach? Zadania logopedy w kształceniu kaznodziejów, w: Profilaktyka logopedyczna w praktyceedukacyjnej, t. 2, red. N. Moćko, 
zagadnień z zakresu homiletyki formalnej ${ }^{66}$. Od wielu lat można również zaobserwować zainteresowanie homiletów zagadnieniami retorycznego wymiaru przepowiadania słowa Bożego. Tematyka ta była także widoczna w opracowaniach homiletycznych ostatniego dziesięciolecia ${ }^{67}$.

$\mathrm{Na}$ podstawie obserwacji oraz badań ankietowych prowadzonych wśród studentów homileci polscy wysuwają postulaty dotyczące dalszej odnowy formacji homiletycznej przyszłych kaznodziejów. Współczesna dydaktyka postuluje systematyczne odchodzenie od metod polegających na przekazie gotowej wiedzy, a skłania się w kierunku metod problemowych i praktycznych, eksponując w ten sposób aktywizujące metody nauczania, pozwalające uczącym się zdobywać wiedzę nie poprzez gromadzenie informacji, jej zapamiętywanie i zrozumienie, lecz poprzez samodzielne jej poszukiwanie i odkrywanie. Również w dydaktyce homiletyki wykłady powinny być systematycznie modyfikowane w kierunku zajęć problemowych i konwersatoryjnych, które bardziej służą samodzielnemu zdobywaniu wiedzy przez alumnów i domagają się od nich inicjatywy i pomysłowości, samodzielności myślowej i twórczego rozwią-

K. Węsierska, Katowice 2013, s. 92-103; L. Szewczyk, Znaczenie terapii logopedycznej w ksztatceniu kaznodziejów, „Logopedia Silesianea” 1 (2012), s. 82-89.

66 D. Chrzanowski, Wybrane kompozycje homilii, w: Jak przepowiadać dziś? Głoszenie Słowa Bożego w służbie chrześcijańskiej wiary, red. S. Dyk, W. Czupryński, Olsztyn 2014, s. 97-109; A. Kalbarczyk, Mnemonika, czyli sztuka pamięci w przepowiadaniu słowa Bożego, w: Ściagać czy nie ściagać? O pomocach do homilii i kazań, red. M. Kubiak, W. Przyczyna, Poznań 2008, s. 49-66; A. Kalbarczyk, Teatr animacji jako medium słowa Bożego. Studium teatrologiczno-homiletyczne, Poznań 2013; H. Sławiński, Prezentacje multimedialne a przepowiadanie homilijne, „Polonia Sacra” (2010), s. 39-52; J. Twardy, Kaznodziejskie oddziaływanie na sferę wolitywną słuchaczy, „Śląskie Studia Historyczno-Teologiczne" 40 (2007) z. 2, s. 390-404; J. Twardy, Obrazowanie w kaznodziejskim głoszeniu słowa Bożego, „Przegląd Homiletyczny” (2013), s. 31-46.

67 T. Lewandowski, Ruch retorycznej odnowy kaznodziejstwa europejskiego-odnowa formy, ,Studia Włocławskie" 10 (2007), s. 280-289; W. Przyczyna, Retoryka a kształcenie kaznodziejów w Polsce, w: Dydaktyka retoryki, red. B. Sobczak, H. Zgółkowa, Poznań 2011, s. 121-129; G. Siwek, Retoryka w procesie kształcenia kaznodziejów, w: Integralne kształcenie kaznodziei, red. W. Broński, Lublin 2006, s. 319-333; L. Szewczyk, Zaprosić retorykę na ambonę. Znaczenie retoryki dla współczesnego kaznodziejstwa, w: Język przekazu religijnego, red. D. Krok, S. Pawiński, Opole 2006, s. 117125; L. Szewczyk, Znaczenie retoryki dla kaznodziejstwa, w: Retoryka, red. M. Barłowska, A. Dacy Budzyńska, P. Wilczek, Warszawa 2008, s. 241-249. 
zywania wielorakich problemów ${ }^{68}$. W polskich opracowaniach homiletycznych ostatniego dziesięciolecia zagadnieniem tym zajmuje się głównie Włodzimierz Broński ${ }^{69}$. Także kilku innych homiletów podjęło tematykę formacji homiletycznej ${ }^{70}$.

Jednym z najważniejszych zadań stojących przed współczesnym duszpasterstwem jest przenikanie głoszenia słowa Bożego pierwotną gorliwością i zapałem apostolskiego przepowiadania. To przemiany społeczno-kulturowe zachodzące we współczesnym świecie sprawiają, że konieczny jest stały proces odnowy kaznodziejstwa i dostosowywania go do potrzeb nowej ewangelizacji. Zagadnienie ewangelizacji i nowej ewangelizacji jest podejmowane również przez polskich homiletów. W ostatnim dziesięcioleciu problematykę tę analizował zwłaszcza Stanisław Dyk ${ }^{71}$. Także inni polscy homileci omawiali zagadnienie przepowiadania słowa Bożego w kontekście nowej ewangelizacji ${ }^{72}$.

68 W. Broński, Formacja homiletyczna alumnów w wyższych seminariach duchownych w Polsce. Studium homiletyczne, Lublin 2007.

${ }_{69}$ Integralne kształcenie kaznodziei, red. W. Broński, Lublin 2006; W. Broński, Formacja homiletyczna alumnów w wyższych seminariach duchownych w Polsce..., dz. cyt.; W. Broński, Kształcenie alumnów w wyższych seminariach duchownych $w$ Polsce do posługi kaznodziejskiej we współczesnym świecie, w: Kapłan w posłudze słowa Bożego, dz. cyt., s. 46-57.

70 K. Panuś, Rola historii kaznodziejstwa w procesie kształcenia kaznodziei, w: Integralne ksztatcenie kaznodziei, dz. cyt., s. 253-261; L. Szewczyk, Dydaktyka homiletyki, w: Dydaktyka teologii, red. K. Sosna, Katowice 2006, s. 81-90; L. Szewczyk, Fonetyka w procesie kształcenia kaznodziejów, w: Integralne kształcenie kaznodziei, dz.cyt., s. 311-318; W. Turowski, Drama w dydaktyce homiletycznej jako sposób poszukiwania nowych rozwiazań skutecznego przepowiadania słowa Bożego, „Roczniki Liturgiczno-Homiletyczne” 58 (2011), s. 239-255; J. Twardy, Kształcenie kaznodziei twórczego, w: Integralne kształcenie kaznodziei, dz.cyt., s. 105-119.

71 S. Dyk, Etapy ewangelizacji we wspótczesnym kontekście pastoralnym, „Roczniki Teologiczne” 54 (2007) z. 8, s. 171-185; S. Dyk, Duch - Słowo - Kościót. Biblijny model ewangelizacji, Lublin 2007; S. Dyk, Przepowiadanie homilijne w kontekście dechrystianizacji, w: In persona Christi. Księga na 80-lecie Księdza Profesora Czesława S. Bartnika, t. 1, red. K. Góźdź, Lublin 2009, 1059-1069; S. Dyk, Biblijne podstawy ewangelizacji, w: Świadectwo w stużbie ewangelizacji, red. W. Przygoda, Lublin 2012, s. 31-53, S. Dyk, Nowa ewangelizacja - konkretne wezwanie, Gubin 2015.

72 A. Draguła, Podmiot przepowiadania w nowej ewangelizacji, w: Wobec Boga i człowieka, red. E. Piotrowski, Zielona Góra-Gorzów Wlkp. 2006, s. 45-62; A. Lewek, Nowa ewangelizacja, w: Leksykon teologii, red. R. Kamiński, Lublin 2006, r. 575-579; L. Szewczyk, Kaznodziejstwo w stużbie nowej ewangelizacji, w: Nowa ewangelizacja wyzwaniem dla Kościoła w Polsce, red. B. Biela, Katowice 2011, s. 293-314. 
Misje parafialne i rekolekcje są ważnym środkiem odnowy życia religijnego, bowiem wzbogacają wiaręi życie wewnętrzne. Zagadnienie przepowiadania słowa Bożego podczas misji i rekolekcji w homiletyce polskiej analizował zwłaszcza śp. Gerard Siwek ${ }^{73}$.

Z całą pewnością polska literatura homiletyczna ostatniego dziesięciolecia porusza znacznie szerszą problematykę niż zasygnalizowana powyżej. Jednak przedstawione w niniejszym opracowaniu tematy publikacji odnotowanych w Bibliografii homiletycznej wydają się dominujące. Pełniejszy opis kierunków badań w homiletyce polskiej jest ściśle powiązany z systematycznym uzupełnianiem braków zawartości bazy elektronicznej. Być może niniejsza publikacja będzie zachętą do bieżącego dokumentowania przez homiletów swojego dorobku oraz stałego uzupełniania Bibliografii homiletycznej. W najnowszych publikacjach homileci polscy realizują wiele postulatów wysuwanych w stosunku do nich. Wskazują na priorytetową rolę homilii w przepowiadaniu słowa Bożego, akcentują mistagogiczny wymiar homilii. Szeroko omawiane są zagadnienia z zakresu homiletyki formalnej, zwłaszcza zaś retorycznego wymiaru przepowiadania. Ciągle natomiast aktualny jest postulat prowadzenia badań recepcji nauki Kościoła na temat przepowiadania słowa Bożego w polskiej praktyce kaznodziejskiej, opracowania najnowszej, powojennej historii homiletyki polskiej oraz słownika homiletycznego. Z cała pewnością kolejnych impulsów do badań dostarczają także dokumenty Kościoła powszechnego omawiające zagadnienia homiletyczne: adhortacja apostolska Verbum Domini Benedykta XVI (30.09.2010), adhortacja apostolska Evangelii gaudium papieża Franciszka (24.11.2013) oraz wydane przez Kongregację ds. Kultu Bożego i Dyscypliny Sakramentów Dyrektorium homiletyczne (10.02.2015).

73 G. Siwek, Misje ludowe, w: Leksykon teologii pastoralnej, dz.cyt., s. 501-507; G. Siwek, Rekolekcje, w: Leksykon teologii pastoralnej, dz.cyt., s. 725-731; G. Siwek, Misje ludowe. Historiateologia - praktyka, Kraków 2009; G. Siwek, Rekolekcje wczoraj i dziś, Kraków 2011. 


\section{Summary}

Kierunki badań w homiletyce polskiej na podstawie zawartości Bibliografii homiletycznej

Baza bibliograficzna pozwala każdemu poszukującemu zlokalizować poszukiwane książki, dysertacje, artykuły, streszczenia i recenzje.Jest cennym źródłem informacji o publikacjachukazujących się w ramach danej dyscypliny naukowej. Dotyczy to zwłaszcza stale aktualizowanych bibliografii elektronicznych. Celem niniejszego opracowania jest prezentacja kierunków badań w homiletyce polskiej na podstawie zawartości elektronicznej Bibliografii homiletycznej. Bibliografia homiletyczna w latach 2006-2015 wzbogaciła się o 800 dodanych opracowań dotyczących zagadnień homiletycznych. W najnowszych publikacjach homileci polscy realizują wiele postulatów wysuwanych w stosunku do nich. Wskazują na priorytetową rolę homilii w przepowiadaniu słowa Bożego, akcentują mistagogiczny wymiar homilii. Szeroko omawiane są zagadnienia z zakresu homiletyki formalnej, zwłaszcza zaś retorycznego wymiaru przepowiadania.

Słowa kluczowe: bibliografia, badania naukowe, homiletyka

\section{Direction of Research in Polish Homiletics on the Basis of the Content of The Homiletic Bibliography}

A bibliographic database allows every researcher to locate desired books, dissertations, articles, summaries and reviews. It is a valuable source of information on publications in a field of a given scientific discipline. It applies in particular to the constantly updated electronic bibliographies. The aim of this paper is to present directions of research in Polish homiletics based on the electronic content of The Homiletic Bibliography. In 2006-2015 The Homiletic Bibliography expanded by 800 added items on homiletic issues. In the latest publications Polish homilists meet many demands formulated in relation to them. They point at a priority role of a homily in preaching the Word of God and emphasise a mistagogic dimension of a homily. Issues related to a formal homiletics are widely discussed, with a special emphasis on the rhetorical dimension of preaching.

Keywords: bibliography, research, homiletics

\section{Bibliografia}

Broński W., Homilia, w: Leksykon teologii pastoralnej, red. R. Kamiński, W. Przygoda, M. Fijałkowski, Lublin 2006, s. 288-291.

Flaszen L., Oracja na jubileusz, „Odra” 5 (2006), s. 14-19. 


\section{Leszek Szewczyk}

Hleb-Koszariska H., O bibliografii dla niewtajemniczonych, Wrocław 1974.

Kuc L., Homiletyka polska po Soborze Watykańskim II, w: Posoborowe publikacje teologiczne w Polsce, red. J. Myśków, B. Przybyszewski, Warszawa 1969, s. 226-233.

Lewek A., Wspótczesna odnowa kaznodziejstwa, z. 1, Warszawa 1980.

Polska bibliografia homiletyczna 1945-2005, oprac. W. Przyczyna, L. Szewczyk, Kraków 2007.

Simon H., Homiletyka polska 1965-2005, w: Polska bibliografia homiletyczna 1945-2005, oprac. W. Przyczyna, L. Szewczyk, Kraków 2007, s. 15-41.

Simon H., Kaznodziejstwo polskie: zdobycze i niedociagnięcia, „Ateneum Kapłańskie” (1993) nr 121, s. 241-256.

Szewczyk L., Odnowa przepowiadania słowa Bożego w (archi)diecezji katowickiej po Soborze Watykańskim II. Studium homiletyczne, Katowice 2009.

Tomczyńska E., Bibliografia dorobku naukowego uczelni źródłem informacji w erze cyfrowych technologii na przykładzie Biblioteki Uniwersytetu Szczecińskiego, „Folia Bibliologica” 51 (2009), s. 91-100.

Twardy J., Stan polskiej homiletyki w latach 1945-1999. Próba oceny i wnioski na przyszłość, „Przegląd Pastoralno-Homiletyczny” 4 (2000), s. 17-37.

Twardy J., Źródła przemian we wspótczesnej homiletyce fundamentalnej, „Śląskie Studia Historyczno-Teologiczne" 39 (2006) z. 1, s. 112-125. 